\title{
RELATIONSHIP BETWEEN CONTRACEPTIVE USE AND OCCUPATIONAL STATUS WITH UNWANTED PREGNACNY RISK AMONG COUPLES OF CHILDBEARING AGE
}

\author{
Novela Sanderina Rumaropen', Lutfi Agus Salim², Salut Muhidin³ \\ ${ }^{1,2}$ Department of Biostatistics and Population, Faculty of Public Health, Universitas Airlangga, 60115 Surabaya, \\ East Java, Indonesia \\ ${ }^{3}$ Macquarie University, Sydney, Australia \\ Corresponding Author: Novela Sanderina Rumaropen \\ E-mail: novelasanderinarumaropen@gmail.com
}

\begin{abstract}
Unwanted pregnancy is a world problem. In 2008, there were 208 million pregnancies in the world, and $41 \%$ of them were unwanted pregnancy. Cross-national reproductive health studies have indicated that the unwanted pregnancy rates remain substantially high in many developing regions, including in Indonesia (Bearak et al. 2018). Unwanted pregnancies in Indonesia increased from 13.6\% in 2012 to $16 \%$ in 2015 . The high rates of unwanted pregnancies are often linked to the gaps in family planning services such as the effective use of contraceptive methods which is also influenced by family socioeconomic backgrounds such as their occupational status. Using the case study at health clinics of PKBI in East Java, this paper attempts to explore the association or relationship between the risk of unwanted pregnancy among couples of childbearing age (CCA) with their use of contraceptive methods and occupational status. A quantitative method of a case-control research design was applied by using a random sampling technique. The study was 50 women couples of childbearing age (15-45 years), who had unwanted and wanted pregnancies. Simple correlation analysis shows that the association are relatively significant between the occurrence of an unwanted pregnancy with the long-term contraceptive use ( $\mathrm{p}$-value $=0.008$ ), and with the employed in occupational status ( $\mathrm{p}$-value $=0.027$ ). However, there is no correlation between the unwanted pregnancy occurrence with the short-term contraceptives use $(\mathrm{p}$-value $=0.118$ ). The study concludes that the use of short-term contraceptive methods and the employed status can still affect the risk of unwanted pregnancies, while the effective use of long-term contraceptive method has a vital role in preventing unwanted pregnancies.
\end{abstract}

Keywords: contraception, unwanted pregnancy, couple of childbearing age, occupation

\begin{abstract}
ABSTRAK
Kehamilan tidak diinginkan (KTD) adalah masalah dunia. Tahun 2008 kehamilan 208 juta kehamilan di dunia, dan $41 \%$ di antaranya merupakan KTD. Beberapa international studi bidang kesehatan reproduksi menunjukkan bahwa angka atau tingkat kehamilan yang tidak diinginkan relatif tinggi di banyak negara berkembang, termasuk Indonesia (Bearak et al. 2018). Kehamilan tidak diinginkan dari seluruh kehamilan di Indonesia meningkat dari 13,6\% tahun 2012 menjadi 16\% tahun 2015. Tingginya angka kehamilan yang tidak diinginkan itu seringkali dikaitkan dengan kesenjangan pelayanan KB seperti efektivitas penggunaan alat kontrasepsi dan juga dipengaruhi oleh latar belakang sosial ekonomi keluarga seperti status pekerjaan. Dengan menggunakan studi kasus di klinik kesehatan PKBI Jawa Timur, studi ini bertujuan untuk mengetahui asosiasi atau hubungan antara resiko kehamilan yang tidak diinginkan pada pasangan usia subur dan kebiasaan mereka dalam penggunaan alat kontrasepsi serta status pekerjaan mereka. Metode kuantitatif dengan desain penelitian "case control” digunakan dalam penelitian ini dan menggunakan teknik random sampling. Sampel dari penelitian adalah 50 wanita pasangan usia subur (15-45 tahun) yang mengalami kehamilan diinginkan dan tidak diinginkan. Analisis statistik menunjukkan bahwa terdapat korelasi yang signifikan antara kejadian KTD dengan penggunaan metode kontrasepsi jangka panjang ( $p$-value =0,008), dan dengan status pekerjaan ( -value =0,027). Namun demikian, tidak terlihat adanya korelasi antara kejadian kehamilan tidak diinginkan dengan penggunaan metode kontrasepsi jangka pendek ( $p$-value $=0,118)$. Studi ini menyimpulkan bahwa penggunaan metode kontrasepsi jangka pendek dan status bekerja masih dapat menyebabkan resiko kehamilan yang tidak diinginkan, sementara itu penggunaan metode kontrasepsi jangka panjang menjadi efektif dan berperan penting dalam mencegah kehamilan yang tidak diinginkan.
\end{abstract}

Kata kunci: alat kontrasepsi, kehamilan tidak diinginkan, pasangan usia subur, status pekerjaan 


\section{INTRODUCTION}

Every year, there are millions of women worldwide to have pregnants during their childbearing age (15-49 years). Their pregnancies include those wanted and unwanted ones. A wanted pregnancy is a planned pregnancy, awaited, and occurred at the proper time. Meanwhile, an unwanted pregnancy is a pregnancy that takes place either in an inproper time (mistimed) or unintended (unwanted) (Daerah Istimewa Yogyakarta Indonesian Family Planning Association, 2016).

According to the 2008 Global Report, there were $41 \%$ of unwanted pregnancies out of 208 million pregnancies. Across nations, the percentage of unwanted pregnancies vary, for example it was $58 \%$ in Latin America, $48 \%$ in North America, $44 \%$ in Europe and $39 \%$ in Africa. Whereas in Asia, it was $37 \%$ of unwanted pregnancies out of 118.8 million recorded pregnancies (Yusof et al., 2018).

In the context of Indonesia, the unwanted pregnancy rates are still very high. According to WHO data, more than 32,000 women were experiencing unwanted pregnancies in 20102014 (Perwiraningtyas and Prasetiyo, 2016). In terms of percentage, this rate increased from $13.6 \%$ in 2012 to $16 \%$ in 2015 (Supriyatna, Dewi, and Wilopo, 2018). This prevalence makes Indonesia with the highest rank of unwanted pregnancy rates in ASEAN.

At the provincial level, the trends of unwanted pregnancies vary. According to the Indonesian Family Planning Association in East Java, the number of unwanted pregnancies in East Java was 572 cases $(27.7 \%)$ in 2014 and decreased to 286 cases $(13.8 \%)$ in 2018. In Surabaya, it has been fluctuated. There were 450 cases $(27.9 \%)$ in 2014 , decreased to 358 cases $(22.2 \%)$ in 2015 , then increased to 362 cases $(22.4 \%)$ in 2016 , but decreased again to 249 cases $(15.4 \%)$ and 199 cases $(12.3 \%)$ in 2017 and 2018, respectively (Daerah Istimewa Yogyakarta Indonesian Family Planning Association, 2016). The highest rates is in West Java, while the second highest is in East Java with $12.2 \%$. At the same time, the effort to end the unwanted pregnancy in East Java ranks third at $9.1 \%$ (Perwiraningtyas and Prasetiyo, 2016).

As a matter of fact, the issue of unwanted pregnancy has links with other reproductive health issues such as maternal mortality. According to the Indonesian Health
Demographic Survey (IDHS), there were 228 cases of maternal mortality due to unwanted pregnancies in 2007, and increased to 359 cases in 2012 (Supriyatna, Dewi, and Wilopo, 2018).

Moreover, the unwanted pregnancy may trigger other problems too, including abortion, low birth weight (LBW), and premature pregnancy. These often occur because unwanted pregnancies' women tend to have less visit to the health services and accordingly tend to have negative impacts on their health status. As a result, this unwanted pregnancy problem could affect the well-being of the mother and infant.

In terms of causes of unwanted pregnancy, there are several reasons. It includes unhealthy measures and conditions before and during pregnancy, such as sexual assault, lack of knowledge about contraception, have more children than planned, have health problems or medical record that can be transmitted to the infants, disabled infants, under-age, and irresponsible partner. In addition, they are also culture-related (Dini, Riono and Sulistyowati, 2016).

According to the Indonesian Family Planning Association, the main causes of unwanted pregnancy are the use of failed contraceptives and the mental unpreparedness of a woman. For adolescents, the causes can include cultural myths, information received, and lack of early sex education (Azinar, 2012). Furthermore, teenagers in adolescent age do not yet have enough skills to make the right and correct decisions to avoid sexual and reproductive risks (Daerah Istimewa Yogyakarta Indonesian Family Planning Association, 2016).

Contraception is commonly said as a method to deliberately prevent pregnancy during sexual activity. In other words, it can be used to be an effective way to avoid unwanted pregnancies. Nowadays, the contraceptive uses are available in various devices and methods, such as condoms, implants, IUD, pills, injections, and contacts (Farida, 2017). The contraceptive methods can be divided into two types: the long-term contraceptives (e.g. birth control IUD and implants) and the short-term contraceptives (e.g. pills, condoms, and injections) (Indonesian Ministry of Health, 2013).

This research will analyze some factors that are associated with unwanted pregnancy. The focused factors in this study are including 
the contraceptive uses and occupational status. It aims to analyze the relationship between contraceptives use and occupation of the CCA with the risk of unwanted pregnancy.

\section{METHODS}

This research is an analytical research with a quantitative approach of descriptive statistics. It provides summaries about the sample and the measures such as bivariate and multivariate analysis by using correlation coefficients.

The data were collected from the clinic of Indonesian Family Planning Association in East Java and the Surabaya Mulyorejo Health Center. The time of this research was between August to October 2019. The population is all CCA aged 15-45 years who have unwanted pregnancies and have visited the clinic of Indonesian Family Planning Association in East Java.

The sample involves two identified groups: the case group and the control group, or so called the case-control technique. The first group or case sample is CCA who have unwanted pregnancies (coded as UP), or do not want to have children and have abortions at the clinic of Indonesian Family Planning Association in East Java. The second group or control sample is CCA who have pregnancies (coded as No-UP) in the work area of the Mulyorejo Health Center. The number of samples is 25 case samples and 25 control samples as calculated by using the Lemeshow formula. The technique of taking samples is simple random sampling at CCA who have experienced unwanted pregnancy and having abortion according to the data provided by the Indonesian Family Planning Association in East Java and on pregnant CCA who are interviewed.

For the analysis, unwanted pregnancy (UP) is set as an independent variable, whereas occupational status and contraceptives use are set as dependent variables. Data was obtained using a questionnaire instrument. Furthermore, the data will be analyzed by each variable and the test of influence using statistical analysis. A univariate test was carried out to describe the characteristics of respondents demanding the frequency distribution. Meanwhile, the bivariate test uses a logistical test to see the relationship between variables.

The study has an ethic clearance from the Faculty of Dental Medicine, Universitas
Airlangga Ethics Commission, with certificate number 559/HRECC.FODM/ VIII/2019.

\section{RESULT}

\section{Characteristics of Respondents}

The contraceptive use is categorized into three groups: 1) not contraceptive use, 2) the long-term contraceptive use, and 3) the shortterm contraceptive use. Meanwhile, the occupational status of CCA are classified into two groups: 1) unemployed (includes not working and being student), and 2) employed (including work as civil servants and private). The following table illustrates the frequency distribution of contraceptive use and occupation of the respondents.

Table 1. Frequency Distribution of Contraceptive Use and Occupation of the Respondents

\begin{tabular}{lrr}
\hline \multirow{1}{*}{ Variable } & \multicolumn{2}{c}{ Total } \\
\cline { 2 - 3 } Contraceptive Use & n & \% \\
\hline No contraception & & \\
Pill & 15 & 30.0 \\
Condom & 13 & 26.0 \\
IUD & 2 & 4.0 \\
Calendar & 5 & 10.0 \\
1-month injections & 2 & 4.0 \\
3-month injection & 10 & 20.0 \\
\hline Total & 3 & 6.0 \\
\hline Occupation & 50 & 100.0 \\
\hline Unemployed & & \\
Student & 30 & 60.0 \\
Civil servants & 1 & 2.0 \\
Private & 6 & 12.0 \\
\hline Total & 13 & 26.0 \\
\hline
\end{tabular}

Table 1 shows that more respondents used the short-term contraceptive methods (pills, condoms, calendars, and injections) as many as 30 people $(60.0 \%)$. Meanwhile, CCA who do did not use contraceptive method was 15 people $(30.0 \%)$ and CCA with the long-term contraceptive method (IUD) were five people $(10.0 \%)$. In terms of occupation, there are more unemployed CCA (not working and student respondents) as many as 31 people $(62.0 \%)$ as compared with the employed CCA as many as 19 people $(38.0 \%)$. Their occupational status can be used to illustrate their economic situation which can influence the number of children 
born to women of childbearing age (WCA) (Hanifah, Asyik and Zulkarnain, 2014).

The use of contraceptive methods is influened by respondents' perceptions on the contraception. At the same time, their perceptions are heavily influenced by myths, experiences, and the information they obtained. Many respondents choose the short-term contraceptives because they consider it to be affordable, easy to get and have low health risk.

The Relationship between Occupational Status and Contraceptives Use with the Risk of Unwanted Pregnancy in Couples of Childbearing Age

Using bivariate and multivariate analyses, Table 2 shows that unemployed CCA who experienced unwanted pregnancy (UP) are 12 people (38.7\%) while who did not experience unwanted pregnancy (No-UP) are 19 people $(61.3 \%)$. There are 13 employed CCA and experience UP (68.4\%), whereas No-UP as many as 6 people $(31.6 \%)$.

Strengthened through the results of statistical tests obtaining a P-value of 0.027 (Pvalue less than 0.05) means that there is a correlation between occupational status and the risk of unwanted pregnancy among couples of childbearing age. Besides, an Odd Ratio (OR) value of 3.929 (OR more than 1) was obtained, meaning that employed couples of childbearing age at risk of 3.929 times having unwanted pregnancy compared to the unemployed ones.
Table 2 also shows the results of multivariate correlations between contraceptive use and the risk of unwanted pregnancies (UP and No-UP) into three parts: 1) the non users and the users of short-term contraceptive methods, 2) the non users and the users of longterm contraceptive methods, and 3) the shortterm users and the long-term users. There are 12 people $(80.0 \%)$ who did not use any contraceptive methods and have unwanted pregnancy (UP). Three people $(20.0 \%)$ are recorded among CCA who did not use any contraceptive methods and do not have an unwanted pregnancy (No-UP). CCA using short-term contraceptives and experiencing unwanted pregnancy are 14 people $(46.7 \%)$. At the same time, CCA with short-term contraceptives and do not experience an unwanted pregnancy are 16 people $(53.3 \%)$.

Supported by the results of statistical tests that show a P-value of 0.118 (P-value of more than 0.05 ) means that there is no correlation between the use of short-term contraceptives (e.g., pills, calendars, injections, etc.) with the risk of unwanted pregnancy in couples of childbearing age. The OR value of 3.143 means that couples of childbearing age who choose short-term contraceptives will have an unwanted pregnancy risk of 3.143 times, compared to CCA, who do not use contraceptives.

Following Table 2, 12 CCA do not use birth control and have unwanted pregnancy $(80.0 \%)$. Three people $(20.0 \%)$ of CCA do not

Table 2. The Relationship of Occupation and Contraceptives Use with the Risk of Unwanted Pregnancy in Couples of Childbearing Age

\begin{tabular}{|c|c|c|c|c|c|c|c|c|c|}
\hline \multirow{3}{*}{\multicolumn{2}{|c|}{ Variable }} & \multicolumn{4}{|c|}{$\begin{array}{c}\text { Unwanted Pregnancy } \\
\text { (UP) }\end{array}$} & \multicolumn{2}{|c|}{ Total } & \multirow[t]{3}{*}{ P-value } & \multirow[t]{3}{*}{$\begin{array}{c}\text { OR } \\
(95 \%)\end{array}$} \\
\hline & & \multicolumn{2}{|c|}{ UP } & \multicolumn{2}{|c|}{ No-UP } & \multirow[b]{2}{*}{$\mathbf{N}$} & \multirow[b]{2}{*}{$\%$} & & \\
\hline & & $\mathbf{n}$ & $\%$ & n & $\%$ & & & & \\
\hline \multirow[t]{2}{*}{ Occupation } & Unemployed & 12 & 38.7 & 19 & 61.3 & 31 & 100 & \multirow{3}{*}{0.027} & \multirow{3}{*}{3.929} \\
\hline & Employed & 13 & 68.4 & 6 & 31.6 & 19 & 100 & & \\
\hline Total & & 25 & 50.0 & 25 & 50.0 & 50 & 100 & & \\
\hline Short-term & None & 11 & 73.3 & 4 & 26.7 & 15 & 100 & \multirow{3}{*}{0.204} & \multirow{3}{*}{2.754} \\
\hline Contraceptives & Short-Term Method & 14 & 26.7 & 15 & 51.7 & 30 & 100 & & \\
\hline Total & & 25 & 56.8 & 19 & 43.2 & 44 & 100 & & \\
\hline Long-term & None & 12 & 80.0 & 3 & 20.0 & 15 & 100 & \multirow{3}{*}{0.008} & \multirow{3}{*}{0.267} \\
\hline Contraceptives & Long-Term Method & 0 & 0.0 & 6 & 100 & 6 & 100 & & \\
\hline Total & & 12 & 60.0 & 9 & 40.0 & 21 & 100 & & \\
\hline \multirow[t]{2}{*}{ Contraceptives } & Short-Term Method & 14 & 46.7 & 16 & 53.3 & 30 & 100 & \multirow{3}{*}{0.069} & \multirow{3}{*}{0.382} \\
\hline & Long-Term Method & 0 & 0.0 & 5 & 100 & 5 & 100 & & \\
\hline Total & & 14 & 40.0 & 21 & 60.0 & 35 & 100 & & \\
\hline
\end{tabular}


use family planning and do not have a unwanted pregnancy. There is no CCA who use long-term contraceptives and have unwanted pregnancy $(0.0 \%)$. At the same time, CCA who use longterm contraceptives and do not experience unwanted pregnancy are 5 people $(100 \%)$.

Strengthened through statistical test results obtained, a P-value of 0.008 (P-value less than $0.05)$ means that there is a correlation between long-term contraceptives use and the risk of unwanted pregnancy in couples of childbearing age. Besides, an OR value of 0.267 (OR less than 1) is obtained, meaning that CCA using long-term contraceptives (e.g., IUD, implants, sterilizers, etc.) have a risk of 0.267 times preventing unwanted pregnancy compared to non-FPIC CCA.

The respondents can choose both types of contraceptives. Each of the contraceptives has different level of effectiveness to prevent unwanted pregnancy. The following is the result of an analysis of the relationship between the use of short-term contraceptives (e.g., pills, calendars, injections, etc.) and the use of longterm contraceptives (e.g., IUD, implants, sterilization, etc.) with the risk of unwanted pregnancy in CCA.

Following Table 2 CCA with short-term contraceptives and experiencing unwanted pregnancy are 14 people $(46.7 \%)$. CCA who use short-term contraceptives and do not experience unwanted pregnancy is 16 people $(53.3 \%)$. CCA who use long-term contraceptives and experience unwanted pregnancy are $0(0.0 \%)$. At the same time, CCA who use long-term contraceptives and do not experience unwanted pregnancy are 5 people (100\%).

Strengthened through statistical test results obtained, a P-value of 0.069 (P-value less than $0.05)$ means that there is no correlation between the use of short-term and long-term contraceptives with the risk of unwanted pregnancy in couples of childbearing age. OR value of 0.382 means that CCA who use longterm contraceptives has a chance of 0.382 times having an unwanted pregnancy compared to CCA who choose short-term contraceptives.

\section{DISCUSSION}

\section{Relationship between Occupation and Risk of Unwanted Pregnancy in Couples of Childbearing Age}

This study has indicated that there is a correlation between occupation and the risk of unwanted pregnancy among CCA. Employed couples of childbearing age are more at risk of unwanted pregnancy compared to unemployed couples of childbearing age. This is because employed couples of childbearing age focus on their work careers. They feel they do not have time to care for the pregnancy and their child at birth. Furthermore, employed couples of childbearing age also anxious of losing their jobs or losing career opportunities in their jobs when they are pregnant and have children.

A study conducted by Anggraini et al. (2018) by using the 2012 Indonesian Demographic and Health Survey (IDHS) data found that the economic level is significantly correlated with unwanted pregnancy $(\mathrm{P}$-value $=$ 0.041). However, the study also explained that poor economic groups dominate unwanted pregnancy since most of poor economic groups use the short term contraceptive methods, such as pills and injection. In fact, the contraceptive pills and injections have low effectiveness. At the same time, those in middle-income, wealthy, and very wealthy countries often use IUDs and other contraceptives that have higher effectiveness.

Other research by Theme-Filha et al. (2016) showed similar results with the conclusions that there was a positive correlation between occupation and unwanted pregnancy occurence. Unemployed women are at risk of unwanted pregnancy. That research finding is somewhat different from Saptarini and Suparmi (2016), which state that there is no correlation between occupation and unwanted pregnancy occurence $(\mathrm{P}$-value $=0.489)$. Both employed and unemployed individuals will be at the same risk for unwanted pregnancy. Contrary to the research by Sari (2016) which states that there is no strong correlation between teenagers who are pregnant with occupation $(\mathrm{P}$-value $=0.069)$. Contrary to research by Suherni and Raharjo (2018), which results in occupation is not strongly related to abortion due to unwanted pregnancy $(\mathrm{P}$-value $=0.237$ )

The differences in those results are due to differences in their population samples and research location. Moreover, the differences in respondents characteristics allow different mindsets too. In this study, employed respondents who have good careers, experience more unwanted pregnancies than unemployed ones. Work is a top priority and vital because it is considered as a source of income to earn a living. Furthermore, the income will be used to 
support life. When someone is working and pregnant, they feel they will be hampered and burdened by the obligation to be a parent, such as caring for their children. Therefore, respondents prioritize work and do not want to get pregnant again.

\section{The Relationship between the Contraceptives Use and Unwanted Pregnancy in Couples of Childbearing Age}

This study so far also indicates that there is a correlation between long-term contraceptives use and the risk of unwanted pregnancy among CCA. The couples of childbearing age who choose short-term contraceptives are at high risk of unwanted pregnancy as compared to those who do not use contraceptives or use long-term contraceptives. CCA with the use of long-term contraceptives have a chance of avoiding unwanted pregnancies compared to CCA that do not use birth control or use shortterm contraceptives. That is because sexually active CCA often forget to use acceptors, and therefore the use of short-term contraceptives has a higher risk of failure.

Our results are confirmed by Ratnaningsih (2018) produces a $\mathrm{P}$-value $=0.001$, meaning that unmet need for family planning influences the occurrence of an unwanted pregnancy. This result is supported by Prastiwi (2017) which states that unwanted pregnancy is related to the use of birth control in the future. These results are in accordance with the study of Perwiraningtyas and Prasetiyo (2016), resulting in a $\mathrm{P}$-value $=0.016$, meaning that there is a correlation between types of contraception with the unwanted pregnancy in couples of childbearing age. The incidence of unwanted pregnancy is related to the use of family planning devices, especially in Indonesia. These results are in line with Saptarini and Suparmi (2016), unwanted pregnancy is more likely to be experienced by couples who use long-term contraceptives than couples who do not use short-term contraceptives. This matter can occur because couples drop out or use nonroutine contraceptives for the modern contraceptives they use. Types of short-term contraceptives such as pills, condoms, and injections have a low level of compliance when compared to long-term contraceptives such as implant, IUD, and medical operative for women (tubectomy) or medical operative for men (vasectomy) or commonly called sterilization.
The results of this study are different from the research of Suherni and Raharjo (2018), which states that there is no correlation between contraceptive use and the incidence of unwanted pregnancy (P-value $=0.773)$. Previous research by Suherni et al. noted that a lack of knowledge about contraceptive use and reproductive health problems causing inconsistency of mothers in using contraception.

\section{CONCLUSIONS AND SUGGESTIONS}

\section{Conclusion}

This study found that the main factors associated with the occurrence of unwanted pregnancy among CCA in these sample population are unemployment and short-term contraceptves use (e.g., pills, injections, condoms, calendars, etc.). At the same time, the factors that can prevent unwanted pregnancy are the use of long-term contraceptive methods (i.e., implants, IUD, tubectomy, or vasectomy).

\section{Suggestion}

Based on the findings, Mulyorejo Health Center can be expected to provide counseling on the prevention of unwanted pregnancy not only to adolescents but also to all women of childbearing age. Mulyorejo Health Center and the Clinic of Indonesian Family Planning Association in East Java can provide advice to mothers to choose the long-term contraceptives (for example, implant, IUD, tubectomy, or vasectomy). Furthermore, it is suggested to companies that have female employers to provide education related to unwanted pregnancy so that increasing awareness on the information about reproductive health and contraceptive use among employed couples of childbearing age.

\section{REFERENCES}

Anggraini, K., Wratsangka, R., Bantas, K. and Fikawati, S., 2018. Faktor-faktor yang Berhubungan dengan Kehamilan Tidak Diinginkan di Indonesia. PROMOTIF: Jurnal Kesehatan Masyarakat, 8(April), pp.27-37.

Azinar, M., 2013. Perilaku Seksual Pranikah Berisiko Terhadap Kehamilan Tidak Diinginkan. Jurnal kesmas, 8 (2), pp. 137145. 
Bearak, J., Popinchalk, A., Alkema, L., and Sedgh, G., 2018. Global, Regional, and Subregional Trends in Unintended Pregnancy and Its Outcomes from 1990 to 2014: Estimates from a Bayesian Hierarchical Model. THE LANCET Global Health, 6(4), pp.e380-e389.

Daerah Istimewa Yogyakarta Indonesian Family Planning Association, 2016. 4 Teori Pendekatan Efektif pendidikan HKSR Terhadap Kaum Muda. [Online]. Available at: https://pkbi-diy.info/4-teoripendekatan-efektif-pendidikan-hksrterhadap-kaum-muda/.

Dini, L.I., Riono, P. and Sulistyowati, N., 2016. Pengaruh Status Kehamilan Tidak Diinginkan Terhadap Perilaku Ibu Selama Kehamilan dan Setelah Kelahiran di Indonesia (Analisis Data SDKI 2012). Jurnal Kesehatan Reproduksi, 7(2), pp.119-133.

Farida, 2017. Penggunaan Alat Kontrasepsi Suntik dan Pil Terhadap Peningkatan Berat Badan pada Ibu Pasangan Usia Subur (di Dusun Gender Desa Karanganom Kec. Kauman Kab. Tulungagung). STRADA Jurnal Ilmiah Kesehatan, 6(2), pp.43-47.

Hanifah, L., Asyik, B., Zulkarnain, 2014. Pengaruh, Pendidikan, Pekerjaan, Usia Kawin Pertama, Penggunaan Alat kontrasepsi Terhadap Jumlah Anak. Jurnal Penelitian Geografi, 2(8), pp. 1-9.

Indonesian Ministry of Health, 2013. Situasi Keluarga Berencana di Indonesia. 2nd ed. Jakarta: Indonesian Ministry of Health.

Perwiraningtyas, P. and Prasetiyo, N.A., 2016. Hubungan Jenis Metode Kontrasepsi dengan Kehamilan Tidak Diinginkan (KTD) pada Pasangan Usia Subur (PUS). Jurnal Ners LENTERA, 4(1), pp.15-25.

Prastiwi, R.S., 2017. Determinan Kejadian Kehamilan Tidak Direncanakan (KTD) di Kabupaten Tegal. In: Seminar Nasional
IPTEK Terapan. Tegal: Poli Teknik Tegal.pp.15-17.

Ratnaningsih, E., 2018. Analisis Dampak Unmet Need Keluarga Berencana Terhadap Kehamilan Tidak Diinginkan di Rumah Sakit Panti Wilasa Citarum Semarang. Jurnal Kebidanan, 7(2), pp.8094.

Saptarini, I. and Suparmi, 2016. Determinan Kehamilan Tidak diinginkan di Indonesia (Analisis Data Sekunder Riskesdas 2013). Jurnal Kesehatan Reproduksi, 7(1), pp.1524.

Sari, D., 2016. Faktor-faktor yang Berhubungan dengan Kehamilan pada Usia Remaja di Puskesmas Ciputat Kota Tanggerang Selatan Tahun 2014. Arsip Kesehatan Masyrakat, 1(1), pp.4-17.

Suherni and Raharjo, B.B., 2018. Demography Characteristic of Married Women and Abortion Behavior in Unwanted Pregnancy. Public Health Perspective Journal, 3(2), pp.131-139.

Supriyatna, Dewi, F.S.T. and Wilopo, S.A., 2018. Intensi Fertilitas Wanita Usia Subur dan Kehamilan Tidak Diinginkan di Indonesia: Analisis Data Performance Monitoring and Accountability 2020. Berita Kedokteran Masyarakat, 34(5), pp.185-193.

Theme-Filha, M.M., Baldisserotto, M.L., Fraga, A.C.S.A., Ayers, S., Gama, S.G.N. da and Leal, M. do C., 2016. Factors Associated with Unintended Pregnancy in Brazil: Cross-Sectional Results from The Birth in Brazil National Survey, 2011/2012. Reproductive Health, 13(118), pp.235-243.

Yusof, M., Samad, A.A., Omar, M. and Ahmad, N.A., 2018. Unplanned Pregnancy and Its Associated Factors. Global Journal of Health Science, 10(8), pp.132-142. 